UNIVERSITY OF MICHIGAN

MUSEUM OF ZOOLOGY

Miscellaneous Publications No. 24

\title{
A Comparative Life History Study of the Mice of the Genus Peromyscus
}

BY

ARTHUR SVIHLA

ANN ARBOR, MICHIGAN

THE UNIVERSITY OF MICHIGAN PRESS

July 8, 1932 

UNIVERSITY OF MICHIGAN

MUSEUM OF ZOOLOGY

Miscellaneous Publications No. 24

\title{
A Comparative Life History Study of the Mice of the Genus Peromyscus
}

\author{
BY \\ ARTHUR SVIHLA
}

ANN ARBOR, MICHIGAN

THE UNIVERSITY OF MICHIGAN PRESS

July 8, 1932 


\section{ADVERTISEMENT}

The publications of the Museum of Zoology, University of Michigan, consist of two series-the Occasional Papers and the Miscellaneous Publications. Both series were founded by Dr. Bryant Walker, Mr. Bradshaw H. Swales, and Dr. W. W. Newcomb.

The Occasional Papers, publication of which was begun in 1913, serve as a medium for the publication of brief original papers based principally upon the collections in the Museum. The papers are issued separately to libraries and specialists, and, when a sufficient number of pages have been printed to make a volume, a title-page, index, and table of contents are supplied to libraries and individuals on the mailing list for the entire series.

The Miscellaneous Publications include papers on field and museum technique, monographic studies, and other papers not within the scope of the Occasional Papers. The papers are published separately, and as it is not intended that they shall be grouped into volumes, each number has a title-page, and, when necessary, a table of contents.

Frederick M. Gaige, Director of the Museum of Zoology, University of Michigan 
TABLE OF CONTENTS

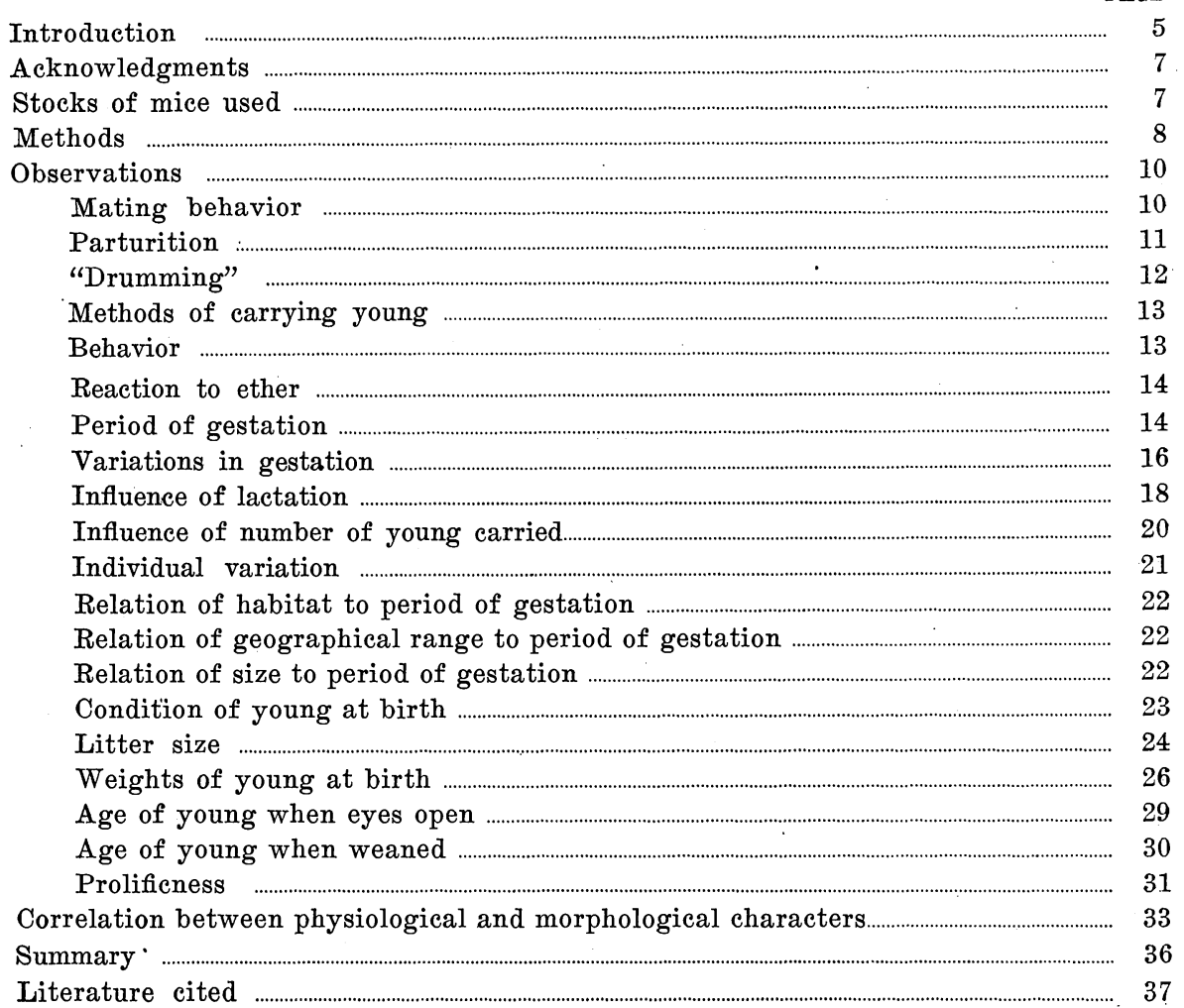




\title{
A COMPARATIVE LIFE HISTORY STUDY OF THE MICE OF THE GENUS PEROMYSCUS*
}

\author{
By Arthur SviHLA
}

\section{INTRODUCTION}

Detailed knowledge of the life histories of the majority of the smaller North American mammals has not yet been secured. This is particularly true of the large group of rodents. Within the past few years a small number of rodents have been studied rather extensively, chiefly on account of their economic importance. Exact details concerning the natural history and particularly the breeding habits of most rodents are still lacking. This condition of our knowledge concerning wild mammals is due in part, perhaps, to a lack of interest, but chiefly to the difficulties involved in rearing them in captivity.

It is necessary to keep these animals under very close observation in order to learn such details of their life histories as the length of gestation and the weight and condition of the young at birth. These important items cannot be obtained by the usual methods of field study.

Some animals are far more tolerant of domestication than others; comparatively few thrive and reproduce readily in captivity. One of the most serious deleterious effects of captivity upon wild animals is the more or less complete failure to breed, even though the animals themselves appear to be in a healthy and normal condition. The phenomenon is well known to keepers of zoological parks as well as others interested in raising wild mammals.

The data presented here for Peromyscus are representative of the virtually uniform conditions obtained in the laboratory, and have not as yet been tested in the field. Such a check would be most desirable, but owing to the nature of the study, it is doubtful whether data on the length of gestation, for example, could be obtained successfully in the field. It is well known that prolificness and rate of reproduction in wild animals may be modified by captivity, but it has not yet been proven that the actual processes involved in reproduction are changed. In fact, the small amount of data available points to the conclusion that these physiological processes are inherent in the race. For example, it is known (Howell, 1927: 1004) that women of the Jewish race menstruate earlier in life than do women of more northern races. Jewish women born in northern climates still menstruate at an earlier age than do native women, showing that such

* A dissertation submitted in partial fulfillment of the requirements for the degree of Doctor of Philosophy in the University of Michigan. 
environmental conditions do not necessarily change these physiological processes.

Previous studies of the life histories of the smaller mammals have usually been made on a few individuals of one species in a genus. The assumption has often been made that the data obtained for one species are applicable to the genus in general. Such an assumption may be correct for some genera but not necessarily so for others. For instance, Bailey (1924) and Selle (1928), working independently on two different species of meadow-mice (Microtus), found that the gestation period (21 days) was the same for the two species. Wade (1927) and Shaw (1925), each working on a different species of ground squirrel (Citellus), found that the length of gestation was different for these species (27 and 21 days respectively). This shows the desirability and even necessity for a more thorough comparative study of the species and subspecies in one genus. Such a study is especially needed to understand better the relationships between the taxonomic groups.

It has been generally assumed by most taxonomists that differences in taxonomic characters which are based upon morphology are accompanied by differences in physiological functions. The majority of taxonomists have had to be satisfied with merely pointing out the resemblances or differences between forms without being able to carry their investigations further. Very few actual data have been presented either to substantiate or refute the hypothesis that morphological differences are accompanied by differences in physiological functions.

Physiological species are definitely recognized by bacteriologists, parasitologists, and entomologists. Entomologists working with aphids and microlepidoptera have recognized species which appear morphologically alike but which are very dissimilar in their physiological requirements (Patch, 1917, and Heinrich, 1923).

Robson (1928) in his book The Species Problem has discussed the correlation between morphological and physiological characters and its taxonomic significance. He gives, for instance, the case of various forms of Trypanosoma brucei which are morphologically alike but which inhabit different hosts and cannot be transferred from one to another. He cites Harris (1916) for correlation between certain morphological and physiological characters in plants; and Harris, Blakeslee, and Warner (1917) for correlation between body pigmentation and egg laying in the domestic fowl.

The genus Peromyscus was chosen for this investigation, for within it are a large number of subgenera, species and subspecies widely and abundantly distributed over the continent of North America. Large stocks of the various species were available in the Murarium of the Museum of 
Zoology at the University of Michigan, where they could be studied at the same time and under virtually the same conditions.

The purposes of this study are (1) to secure data on the life history of the genus Peromyscus : for a comparative study of the period of gestation, the number of young per litter, the condition of the young at birth, the age when their eyes open, the age when weaned, and the possible numbers of litters per year; and (2) to determine by statistical methods, differences and similarities in these reproductive processes between subgenera, species, and subspecies, thus presenting actual data which will substantiate or refute the general hypothesis that differences and similarities in morphological characters upon which taxonomic divisions are based, are correlated with differences and similarities in physiological functions.

\section{ACKNOWLEDGMENTS}

I wish to express my gratitude and indebtedness to the Division of Mammals, Museum of Zoology, of the University of Michigan, for facilities and support given this study, and to Lee R. Dice, Curator of Mammals, for helpful advice and criticism.

\section{Stocks of Mice Used}

Three species, Peromyscus (Peromyscus) maniculatus, leucopus, and truei, and the two species, P. (Haplomylomys) californicus and eremicus, were studied. These species and their subspecies are distributed over North American as follows.

\section{Peromyscus (Peromyscus) maniculatus}

This is the most widely distributed species of the genus. It has representatives from Labrador to Alaska and from just south of the Arctic Circle to the Isthmus of Tehuantepec in Mexico. It is, perhaps, the most plastic of all the deermice for it has been modified into more than 43 geographical races or subspecies. Of these subspecies 8 were studied, as follows :

artemisiae from Godman Springs, Blue Mountains, Columbia County, Washington, at an altitude of 5,700 feet; and from the junction of the Palouse and Snake rivers, Washington.

bairdii from Ann Arbor, Michigan; Grafton, North Dakota; and Alexander, Iowa.

blandus from Alamogordo, New Mexico.

assimilis from North Coronado Island, Lower California.

gambelii from La Jolla, California.

osgoodi from three localities in Daggett County, northeastern Utah, viz., Linwood, at an altitude of 6,000 feet; Sheep Creek, 6 miles south of 
Linwood, 6,200 feet; and Summit Springs, 10 miles south of Linwood, 8,000 feet.

rubidus from Carlotta, California.

rufinus from Buena Vista, Colorado, and Clouderoft, New Mexico.

\section{Peromyscus (Peromyscus) leucopus}

This species is also widespread over eastern North America and Mexico and contains 13 subspecies. The 2 subspecies studied were:

leucopus from Asheville, North Carolina. This region, according to Osgood (1909: 114) is an area of intergradation between leucopus and noveboracensis. The reference of the stock to leucopus is tentative.

noveboracensis from Ann Arbor, Michigan; Holland, Michigan; Wooster, Ohio; Cedarvale, New York; and Marshall, Missouri. Marshall is in another area of intergradation between leucopus and noveboracensis. These mice are apparently nearer the latter subspecies.

\section{Peromyscus (Peromyscus) truei truei}

The mice of this species are all found in the southwestern United States and Mexico. TThose studied came from Highrolls, New Mexico, and from Mesa de Maya, Colorado.

\section{Peromyscus (Haplomylomys) californicus californicus}

The largest deermice found in the United States belong to $P$. californicus, which occurs in the coastal region of California south to northern Lower California. Stocks of this species came from Corralitos, California.

\section{Peromyscus (Haplomylomys) eremicus eremicus}

This species occurs in the Sonoran region of the border states, Lower California, and Mexico. The stocks of these mice were from Carrizozo, New Mexico.

\section{METHODS}

All the mice under observation were kept in the Murarium of the Museum of Zoology at the University of Michigan under virtually identical conditions, so that if any differences occur they must presumably be inherent rather than modifications caused by the environment. The conditions and methods of rearing the mice have been described by Dice (1929).

For the greater part of three years (September to June 1927-28 and 1928-29, and from September to May 1929-30), investigations concerning the reproductive processes and early development of these mice were carried on. Especial attention was given to the period of gestation, the number of young at birth, and the age attained before the eyes opened. Data bear- 
ing upon some one or more phases of the reproductive processes were obtained from 140 pairs of these mice representing 5 species and 12 subspecies.

Strictly speaking, the length of gestation is the period of time from the fertilization of the egg to the birth of the young. As no method has, as yet, been devised for ascertaining the time of fertilization without killing the animal, the date of copulation has been taken to be approximately the same as the time of fertilization. Hence, the length of gestation is calculated from the time of copulation to the date upon which the young are born. In support of this method of calculation, the observations of Sobotta (1895) and Sobotta and Burckhard (1911) may be cited. Sobotta worked on the fertilization in the mouse (Mus musculus) and later Sobotta and Burckhard investigated the rat (Rattus sp.). They found that the time of copulation was practically the same as that of fertilization, since the spermatozoa were incapable of living in the generative tract of the female for more than an hour. More recent work (Hammond and Asdell, 1926), however, indicates that 30 hours is more nearly the maximum period that spermatozoa may remain alive after copulation.

Since deermice are chiefly nocturnal and particularly active during the early hours of the night, this is the most favorable time for copulation to occur. In fact, actual observations of several pairs of mice showed that copulation took place from seven to nine o'clock in the evening. One pair of mice was observed to copulate during midday.

The length of the period of gestation was ascertained in the following manner : a pair of mice was placed in a cage together. After two weeks time they were inspected. If the female appeared pregnant, the male was removed from the cage until the young were born. In order to make sure that no litters were overlooked, the mice were examined twice daily, once in the morning and again in the evening. As soon as the young resulting from this mating were found in the nest, the male was again placed in the eage and left there until the following morning, usually not more than 12 hours and never more than 24. This method was used in order to take advantage of the fact that the females are almost always in oestrum immediately following the birth of a litter and will then accept the male. The time elapsing between the date of the second introduction of the male and the birth of the second litter was taken as the length of the gestation period.

The condition, number, and weights of the young were noted at the time of birth. During the early days of development, the young, as a rule, were not disturbed. In some litters one individual was taken each day in order to determine the rate of growth of the hair and other body characters. Later, the young were removed from the mother in order to measure gesta- 
tion periods which were not influenced by lactation. Observations of the mice were made twice daily in order to ascertain the time when the eyes opened. These latter data were accurate to within 12 hours.

\section{OBSERVATIONS}

MATING

Like a number of other rodents which have been observed, i.e., Microtus (Bailey, 1924), Clethrionomys (A. Svihla, 1929), and Oryzomys (A. Svihla, 1931), females of the genus Peromyscus are polyoestrous. They are usually in heat immediately following the birth of a litter. In general the mating behavior of the deermice is very similar to that of Microtus, Clethrionomys, and Oryzomys.

When not with females, the males of Peromyscus maniculatus or $P$. leucopus are usually kept in cages next to the females and indicate sexual excitement by the appearance of the partly descended testes.

When a male is placed with a female, following the birth of a litter, fighting usually results. This is, perhaps, because the female considers the male an interloper and fights him to protect her young. If the female is in heat, the mice soon become accustomed to each other and are quiet. Then the female follows the male about, smelling his perineum. After she has followed the male a short time, he, in turn, follows her in a similar manner and attempts to copulate. Odor and tactile sensations are evidently potent stimuli for arousing sexual activity. The female runs a short distance away from the male and then stops. He follows and copulation takes place. Three copulations have been observed to occur within as short a time as five minutes. The act of copulation itself takes but a few seconds.

After each copulation, in all the instances observed, the males and females lick themselves thoroughly especially about the genital region. After a few copulations have taken place, the female loses her desire to copulate. The male usually attempts to continue, but after she has bitten him a few times, he desists.

After copulation, the male and female may occupy the same nest together with the newly born young. They get along very peacefully until just before the birth of the second litter. At this time the female forces the male and the young of the first litter out of the nest. They then gather enough material to build a nest for themselves in the corner of the cage and are not molested by the female.

Pregnancy is indicated by body swelling as early as the twelfth day.

The females of both species in the subgenus Haplomylomys are evidently not in heat immediately following parturition (differing in this respect from those of the subgenus Peromyscus) for all attempts to breed these 
species at this particular time failed. It was necessary to place the male and female together at intervals and wait until it could be definitely determined whether pregnancy had or had not occurred before other matings were made. Detection of pregnancy by body enlargement was difficult since these species do not have large litters.

\section{Parturition}

Although parturition in wild animals has seldom been observed and recorded, I have witnessed the process in the deermice several times. One morning I noticed that a female of $P$. m. artemisiae (no. 3425) had just given birth to one young and from her still gravid condition, more young were to be expected. I placed her and her young in a battery jar in order to observe the act more closely. The new location evidently disturbed her for she moved about uneasily for a while and made several tours of inspection around the jar. After a short time she appeared satisfied and became quiet. At intervals she got up on her hind legs and stretched. The young in the uterus were plainly seen to move as she did this. As the time of parturition evidently approached, she became uneasy and assumed a squatting position. She then cleaned herself thoroughly by licking, repeating the licking of her forepaws several times. She then bent over and pulled the region surrounding the vulva aside with her paws and simultaneously with a contraction of the abdominal muscles, the head of a young mouse appeared. She assisted the action of the abdominal muscles by pulling gently on the young mouse with her teeth. As the remaining part of the young became exposed, she licked it thoroughly. As soon as delivery was completed she picked up the newly born mouse and licked it thoroughly again. It was still attached to the uterine placenta by a long thin umbilical cord. The mother replaced the mouse on the floor of the jar and after bending over again, the placenta appeared. This she ate, during which process the umbilical cord was broken by stretching. The part of the cord attached to the young evidently dries up shortly after birth. I have never seen a female intentionally cut the cord with her teeth. It is always broken by stretching.

After eating the placenta and the attached parts of the umbilical cord, the mother again licked herself thoroughly, paying particular attention to her paws. She then placed the young mouse under her body and rested. In a few moments she got up and stretched herself as before. The next delivery was a breach one. The mother went through the same operations as those described for the first delivery. The tail and hind legs appeared first and then a portion of the body with the front legs. She assisted the entire delivery with her teeth as described above. The placenta and umbilical cord were disposed of as before. 
It took an hour for this litter of three young to be born. Within two hours after birth, the young were found attached to the nipples and nursing. Two of the young immediately after birth weighed 1.5 and 1.7 grams respectively.

Another female, P. m. blandus (no. 1937), was disturbed while in the act of giving birth to a family of young. In fact, one had just been born and was still attached to the placenta which was within the uterus. Upon being disturbed, the female jumped out of the nest and in so doing the umbilical cord was broken. By the time she reached the corner of the cage, about five inches from the nest, two more young together with their placentas and the first placenta were extruded almost simultaneously without any help from the mother.

Seton (1920) recorded female deermice which were found dead with a family of newly born young, death having evidently resulted from parturition. Upon one occasion a female $P$. m. bairdii (no. 4324) was found dead with the head of a young mouse just emerging from the vaginal opening.

Parturition may often be delayed. For instance, upon one occasion, I found a newly born mouse in a nest and although I watched the mother for over an hour, she did not give birth to any young during this time. Several hours later, however, the nest was again examined, and four more mice had been born.

Upon another occasion, after observing a gravid female for over an hour, I was called out of the room for about five minutes. Upon my return, I found that one young had been born in the interim. During another hour spent in observation, no young were born. After an hour's absence, the nest was re-examined and found to contain two more young.

\section{"Drumming"}

Deermice have been observed to move their front paws rapidly up and down against some resonant object, thus emitting a "drumming" sound. This habit was first described by Walton (1905). Seton (1920), in his work on the breeding habits of Peromyscus leucopus noveboracensis, stated that during the period of his observations, he had never seen a female "drum," although he kept several under observation for a number of weeks. During this time he noticed that only the males made the noise.

During the present investigation, "drumming"' has been observed upon numerous occasions. Both sexes and members of all species and subspecies, with the one exception of $P$. californicus, were found to "drum." The "drumming" noise is usually made after the mice have been disturbed in some way, as, for instance, when they were transferred from one cage to another. Such species as $P$. leucopus and $P$. maniculatus, which are small, nervous, and easily excited, "drum" more often and under less 
provocation than do the larger, less excitable $P$. truei and $P$. eremicus. Not all individuals were found to "drum," and as Seton did not have a large series under observation, his incorrect conclusion that the females do not "drum" may have been due to individuality.

\section{Methods of Carrying Young}

The mother deermouse transports her young either collectively by dragging them attached to her mammae, or separately by carrying them one at a time in her mouth.

Seton (1920), Nelson (1918), and others have described the first method. It is used when the mother is suddenly disturbed and flees from her nest. The young, which are firmly attached to the elongated teats, are dragged along the ground. During the first few days after birth, they act as dead weights to the mother, but when somewhat older, they push with their hind feet against the ground, thus assisting the movements of the parent. This method of transportation is necessarily awkward for the mother when as many as 6 young are hanging on the nipples. Seton (1920) states that evidently only the inguinal nipples are used in transporting the young, but according to my observations both the pectoral and inguinal teats may be used. A whole litter of 6 young together with the mother have several times been picked up from the floor of the cage by holding the tail of one of the young which was attached to a pectoral teat. Young of $P$. californicus and $P$. eremicus are not easily forced to relinquish their hold. Should a young mouse lose its grip on a teat while being moved, it squeaks loudly but after a short time quiets down. The mother, having brought the rest of the family to a safe place, returns for the lost one and carries it to safety in her mouth. This second method has been described by Seton (1920) and Hall (1928). The mother picks the young mouse up in her paws and places it belly-side up in her mouth with her incisors around it rather than pinching a piece of the skin between them. The young mouse, if it is large enough, curls itself about the neck of the mother clinging with its tail and paws.

\section{BeHAVIOR}

Very little experience in handling live deermice is necessary in order to realize the marked differences in behavior between the various species and subspecies. Some are quiet, tractable, and easily handled, whereas others exhibit a nervousness and excitability which persists during the entire period of captivity.

While a species or subspecies may, as a group, be termed excitable or tractable, there is a great deal of individual variation. Some individuals 
of a subspecies which is, on the whole, tractable, may be relatively nervous. The converse is also true.

These differences in behavior have had an important effect upon the amount of data obtainable concerning the reproductive processes. The nervous and excitable mice were not only harder to handle, but they also bred less frequently than those which were more tractable.

In Peromyscus maniculatus, the subspecies osgoodi, artemisiae, blandus, and rufinus are generally easily handled and tractable. The subspeeies bairdii and assimilis are relatively irritable and nervous. The subspecies $P$. leucopus leucopus and $P$. leucopus noveboracensis are also very excitable and difficult to handle. $P$. true $i$ is extremely nervous, especially the females with young. When disturbed, females have been observed to rush wildly about the cage for a long time and even turn somersaults while carrying young mice in their mouths. Both $P$. (Haplomylomys) californicus and $P$. (Haplomylomys) eremicus are quiet and docile in captivity. The large, slow-moving $P$. californicus is especially tractable and easy to handle.

In spite of the fact that the species of Haplomylomys were found to be less nervous and excitable in captivity than some of those of Peromyscus, they did not breed as readily or as frequently and are probably naturally less prolific. Success in breeding depends upon a number of factors, some of which may tend to counteract others.

\section{ReAction to Ether}

The method of marking young mice (Dice, 1929) involves the use of ether as an anaesthetic. A considerable difference in reaction to this anaesthetic is evident between $P$. maniculatus and $P$. leucopus. This is true of the adult mice as well as the young. $P$. maniculatus may be exposed to the anaesthetic without fatal results until practically all movements of the limbs have ceased. P. leucopus must be watched very closely and removed from the anaesthetic jar before movements have ceased or else consciousness will usually not be regained.

Differences in sensitivity to anaesthesia have been reported for the house mouse by Edgar Allen (1922).

\section{Period of Gestation}

Only two papers (Sumner, 1916, and Seton, 1920) have been found which have any bearing upon the length of gestation in the deermice. Sumner reports gestation periods in several subspecies of $P$. maniculatus. His observations upon the duration of gestation were incidental to his main study of geographical variations. His method was to place a male mouse in a cage with two or three females for about twenty days before separat- 
ing them. The dates of introduction and separation of the male were recorded. The minimal interval between the introduction of the male and the birth of the young was taken as the actual period of gestation and was found to be 22 days in 5 cases. He states (p. 271) that in "all but five cases . . . out of a total of 206 broods . . . the figures were greater than this." The maximal interval between the removal of the male and the discovery of the young was taken as a control, and this was found to be a fraction over 22 days. From these data, Sumner concludes that the period of gestation, in some instances at least, does not exceed 22 days.

Seton (1920) observed the breeding habits of P. leucopus noveboracensis and found that the gestation period was 23 days in one instance and apparently 16 in another.

In the present series of observations, a total of 146 gestation periods, accurate to within 24 hours or less, have been ascertained for deermice (Table 1). This is by far the greatest number of accurate periods ever recorded in this or any other genus of native North American rodents.

\section{Peromyscus (Peromyscus) maniculatus}

In this group of subspecies, 90 periods of gestation were ascertained, distributed among 7 subspecies. In the species as a whole, the duration of gestation was found to vary from 22 days to 35 days. A similar variation was found in the gestation periods of those subspecies in which 14 or more periods were recorded. In those subspecies such as bairdii, gambelii, and rubidus, in which only a few periods of gestation were recorded, the periods fell within the limits of the lengths of gestation found in the other subspecies.

By comparison of the means and extremes of the lengths of gestation of non-lactating females for the various subspecies of $P$. maniculatus it will be noted from Table I that there is no significant subspecific difference in regard to this character. The constancy in the mean gestation periods among the subspecies parallels the constancy of morphological characters which distinguishes the species as an entity. The physiological homogeneity among the subspecies is further emphasized by the fact that periods of gestation obtained when two different subspecies are mated (gambelii and artemisiae) fall within the limits of the lengths of gestation for the species as a group.

\section{Peromyscus (Peromyscus) leucopus}

A total of 44 periods of gestation was observed for this species, 11 for the subspecies leucopus, and 33 for the subspecies noveboracensis. For $P$. leucopus, as a whole, the duration of gestation ranged from 22 to 37 days. This range is practically the same as that found for $P$. maniculatus. As 
in $P$. maniculatus, the lengths of gestation varied within the subspecies as much as within the species as a group. In subspecies leucopus the variation was from 22 to 35 days. This is not significantly different from the variations found in subspecies noveboracensis, which ranged from 22 to 37 days. As in $P$. maniculatus, the subspecific variations in the lengths of gestation in $P$. leucopus are similar and of the same magnitude as for the species. The means of the non-lactating females of both subspecies, within limits of error, were found to be the same.

\section{Peromyscus (Peromyscus) truei}

In this species, but one subspecies, $P$. truei true $i$, was available for study. A total of 6 gestation periods was obtained. These varied from 25 to 40 days.

\section{Peromyscus (Haplomylomys) californicus}

Five gestation periods were recorded for this species, varying from 21 to 25 days. As has been stated previously, the females of $P$. californicus were not in heat immediately following the birth of a litter. Thus, only a few gestation periods were recorded; all were of non-lactating females.

\section{Peromyscus (Haplomylomys) eremicus}

A single gestation of 21 days' duration was recorded for this species. As in $P$. californicus, the females were not in heat immediately following parturition. Consequently only one gestation period was obtained. It was for a non-lactating female.

In summary, the periods of gestation in the subspecies of $P$. maniculatus and $P$. leucopus vary within practically the same wide limits. $P$. truei shows in general a somewhat higher range of variation. The data for $P$. californicus refers to non-lactating females and shows decidedly narrower limits of variation.

There is a strikingly wide variation in Peromyscus in the lengths of gestation of the subgenera, subspecies, and even in individual mice. The probable cause of this wide variation is discussed later.

\section{Variations in Gestation}

In the length of periods of gestation recorded for the deermice, there is a variation of 15 days between the shortest and longest. That such a wide variation is not restricted to deermice, is evidenced by records for other mammals. Daniel (1910) reported 10 gestation periods for the house mouse (Mus musculus) which varied from 22 to 30 days. King (1913), in her study of the albino rat, also found an 8 day variation between the shortest and longest period. Kirkham (1916), duplicating 
Daniel's work, recorded variations in the lengths of gestation. Nakamura (1926) reported that the gestation periods of first litters of house mice varied from 17 to 19 days. Selle (1928) found that the duration of gestation in Microtus californicus varied from 21 to 23 days. Lataste (1886) recorded variations in the gestation of certain north African mammals. A. Svihla (1929) found that the gestation period varied from 17 to 19 days in the red-backed mouse (Clethrionomys gapperi gapperi).

The range of variation in the gestation periods of domestic animals has also been determined. Franck, Albrecht, and Göring (1901) found that the gestation in the cow varied from 240 to 311 days. Pinard (1905) recorded a variation of from 275 to 290 days for the same animal. He also recorded the variations in gestation for several other domestic mammals as follows : pig, 116-125 days ; sheep, 147-151 days ; dog, 58-65 days ; cat, 5060 days; rabbit, 27-34 days. Darwin (1875), reporting different gestations in dogs, stated that larger dogs usually have longer gestation periods than smaller ones. He noted a similar condition for sheep.

TABLE I

PERIODS OF GESTATION

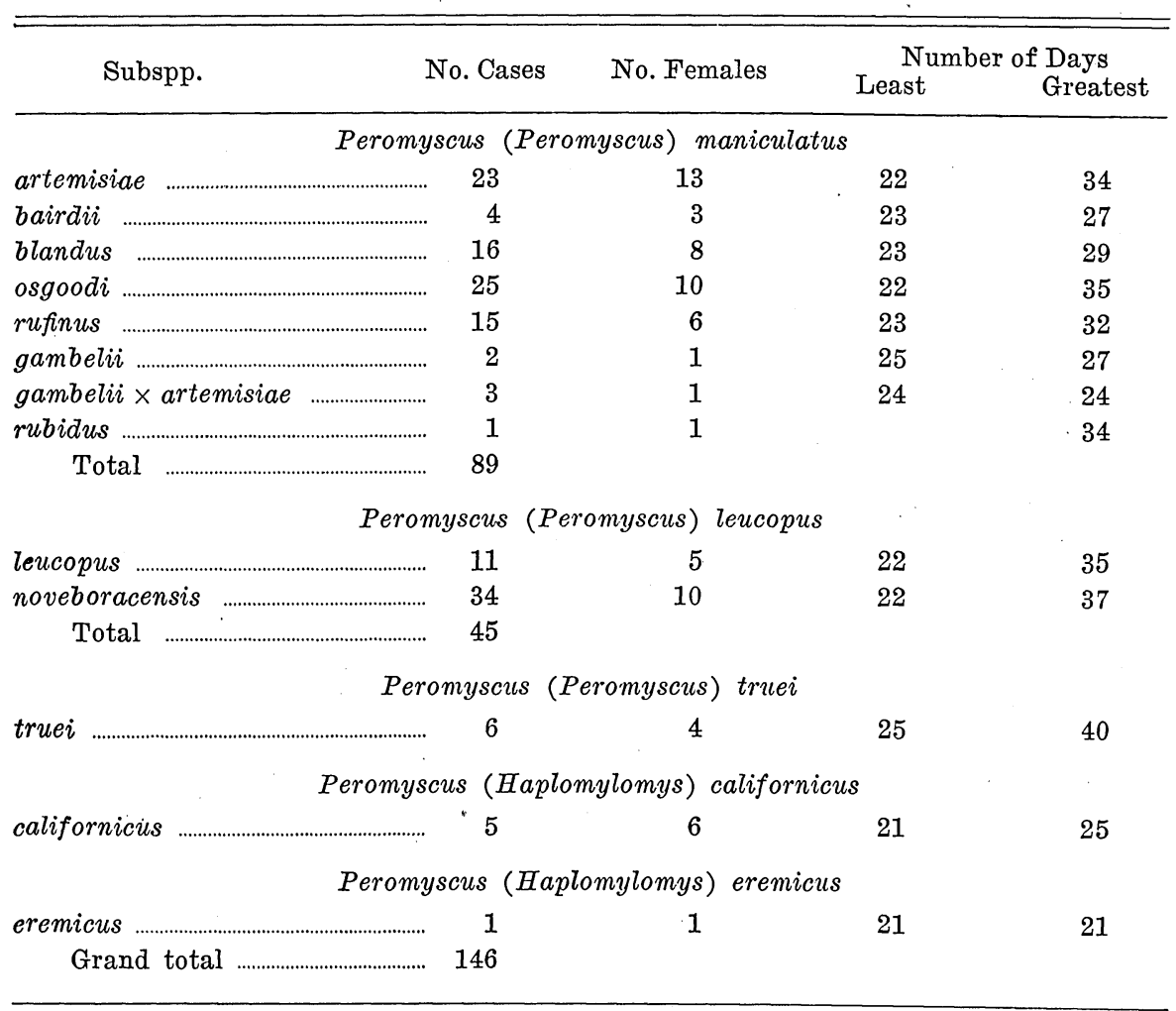


In human beings, the duration of gestation is not exactly known, although it is usually calculated from the date of the last menstruation to the date of delivery. Variations in this period from 231 to 334 days have been known, according to Allen (1907), who summed up the literature bearing on this subject. This wide variation may be ascribed partly to the fact that the date of fruitful coitus is not usually known in man. Lowenhardt (1872) has shown that two women with the same date of coitus had different dates of delivery. In the instance of the horse in which the exact date of copulation is usually known, since the mare is commonly served but once by the stallion, the length of gestation is known to vary from 307 to 412 days (Franck, Albrecht and Göring, 1901).

\section{INFLUENCE OF LACTATION}

During the early period of this investigation, it was noted that when newly born young were killed by the mother shortly after birth, the following gestation (copulation having occurred soon after parturition) was usually shorter than when a litter of mice was nursed during pregnancy. Lactation was thus indicated as a probable factor in lengthening gestation.

Lataste (1886), working on a number of north African mammals, found that lactation during pregnancy had a lengthening effect upon gestation.

According to Daniel (1910) the gestation period of the house mouse (Mus musculus) was increased in proportion to the number of young suckled during pregnancy. He formulated a rule, based upon 10 cases, that one day was added to the normal gestation period for every mouse suckled. Thus, if 5 mice were suckled, the gestation period would be increased by 5 days; if 10 were suckled, an increase of 10 days would be expected in the length of gestation.

King (1913) found a similar influence of lactation upon gestation in the rat (Rattus norvegicus), but she did not find that Daniel's rule applied. She reported that when a large number of young were suckled, the length of gestation was always increased. The duration of gestation was also increased when a very large number of embryos was carried.

Kirkham (1916) duplicated Daniel's study and although he did not verify Daniel's rule, he did find that lactation increased the length of gestation. He later undertook an embryological investigation to explain the effect of lactation upon gestation. He found that in non-lactating house mice (Mus musculus) implantation of the embryos occurred normally on the seventh day after fertilization. He recorded further that in lactating females implantation did not occur on the seventh day but that the embryos lie free in the lumen of the uterus until the fourteenth day, at which time they become implanted. Development of the embryos of both lactating and non-lactating females is the same to the seventh day. Fourteen 
TABLE II

LENGTH OF PERIOD OF GESTATION OF PEROMYSCUS

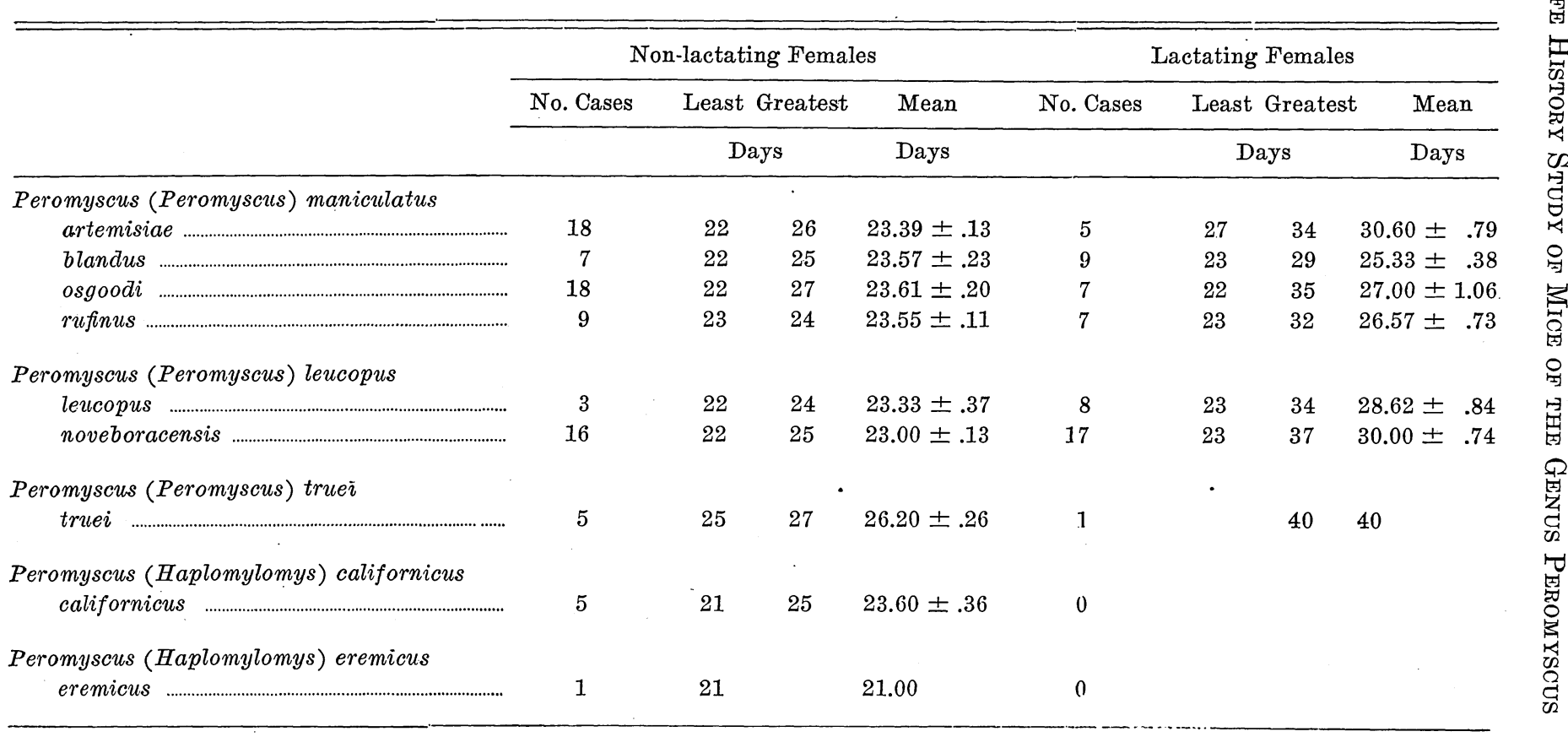


days after birth, the young of the suckling litter open their eyes and commence to be weaned. The nourishment provided by the mother for the suckling young up to this time is then apparently transferred to the embryos for their implantation and further development. Thus, the increased length of gestation in lactating house mice is owing to the delay in implantation of the embryos, which in turn is caused by the utilization of the available nourishment by the suckling young.

In Peromyscus, lactation was found to increase the length of gestation. In Table II, the influence of lactation upon gestation in $P$. maniculatus and $P$. leucopus is shown. It will be noted that for non-lactating females of both $P$. maniculatus and $P$. leucopus, the lengths of gestation are practically the same (23 days). In $P$. truei, for which 5 cases of non-lactating females are recorded, the period of gestation is 26.2 days.

In Peromyscus (Haplomylomys) californicus, the 5 cases of gestation recorded were all for non-lactating females and showed a mean of 23 days. The one instance recorded for $P$. (Haplomylomys) eremicus was 21 days for a non-lactating female.

It may be said in general that the gestation periods for all the nonlactating mice studied was about 23 days, except for $P$. truei, which had a mean gestation period of 26.2 days.

Comparing the data obtained in the genus Peromyscus for lactating females with those for non-lactating females, it will be noted by referring to Table II that the gestation periods for non-lactating females vary within narrow limits, while those for lactating females are far less constant and always longer. This shows clearly that the prolongation of gestation is due to lactation.

Since lactation materially influences the length of gestation, it becomes necessary in securing data concerning the gestation periods of mice to record whether the females are lactating or not. In a comparative study, either data pertaining to non-lactating females or those pertaining to an equal number of lactating and non-lactating females, should be used for comparable results. This type of data is easily secured by removing the young at birth.

\section{Influence of the Number of Young Carried}

It was at first suspected that the number of embryos carried by the mother might have been a factor in causing the variations in length of the periods of gestation recorded above. King (1913) found that in the albino rat (Rattus norvegicus) the gestation period was prolonged when the number of embryos was greater than normal. Kirkham (1916), studying the house mouse (Mus musculus), did not find that the number of embryos carried had any influence upon the length of gestation. 
From the data secured in the study of Peromyscus, no significant prolongation of gestation, because of the greater number of embryos carried, was found. This is shown in Table III, where the gestation periods of nonlactating females of the species $P$. maniculatus are arranged according to the number of young born. The gestations of all subspecies in this species are grouped together since it has been shown that there is no significant difference between them. It will be noted that the average lengths of gestation of females carrying 7 young are not significantly different from those females carrying but 2 young. A similar condition exists for the species $P$. leucopus. Hence, in deermice, no correlation between the number of young carried and the length of gestation is apparent.

TABLE III

INFLUENCE OF THE NUMBER OF YOUNG CARRIED ON THE PERIOD OF GESTATION

\begin{tabular}{|c|c|c|c|c|}
\hline \multirow{2}{*}{ No. Young } & \multirow{2}{*}{ No. Cases } & \multicolumn{2}{|c|}{ Period of Gestation } & \multirow{2}{*}{ Mean. } \\
\hline & & Shortest & Longest & \\
\hline & & \multicolumn{2}{|c|}{ Days } & Days \\
\hline \multicolumn{5}{|c|}{ Peromyscus (Peromyscus) maniculatus } \\
\hline 1 & 4 & 23 & 25 & $24.00 \pm .24$ \\
\hline 2 & 6 & 23 & 24 & $23.33 \pm .13$ \\
\hline 3 & 11 & 22 & 25 & $23.45 \pm .16$ \\
\hline 4 & 14 & 22 & 26 & $23.36 \pm .18$ \\
\hline 5 & 7 & 22 & 24 & $23.29 \pm .18$ \\
\hline 6 & 7 & 23 & 26 & $23.86 \pm .25$ \\
\hline 7 & 7 & 23 & 27 & $23.86 \pm .34$ \\
\hline \multicolumn{5}{|c|}{$\mathrm{r}=-.012 \pm .092$} \\
\hline \multicolumn{5}{|c|}{ Peromyscus (Peromyscus) leucopits } \\
\hline 1 & 1 & 25 & 25 & 25.00 \\
\hline 2 & 1 & 24 & 24 & 24.00 \\
\hline 3 & 3 & 22 & 24 & $23.33 \pm .37$ \\
\hline 4 & 9 & 22 & 24 & $22.67 \pm .15$ \\
\hline 5 & 3 & 23 & 23 & 23.00 \\
\hline 6 & 3 & 23 & 23 & 23.00 \\
\hline \multicolumn{5}{|c|}{$\mathrm{r}=-.89 \pm .7$} \\
\hline
\end{tabular}

\section{INDIVIDUAL VARIATION}

It was found that the same female often varied greatly in the length of the gestation period. For instance, in P. m. osgoodi female no. 4618,4 consecutive gestations were recorded as 24, 27, 29, and 23 days respectively; P. m. blandus female no. 1936, 5 gestations, 23, 29, 24, 24, and 23 days; P. $m$. artemisiae female no. 3425,4 gestations, $33,31,28$, and 24 days. In every gestation longer than 24 days, the female had been nursing a previous 
litter while pregnant. For females which were not suckling young during pregnancy, the gestation periods also varied but to a distinctly less degree. For instance, for $P$. m. osgoodi female no. 4128, 6 consecutive gestations were recorded as $22,24,23,22,24$, and 23 days; for $P$. m. rufinus female no. 4361, 6 gestations, 24, 23, 24, 23, 24, and 23 days. Other similar cases could be cited.

Similar variations in the gestation periods of individual lactating and non-lactating females of the species $P$. leucopus exist.

\section{Relation of Habitat to Period of Gestation}

The ecological habitats of the different subspecies of $P$. maniculatus differ widely. For instance, $P . m$. bairdii is an inhabitant of the humid prairie lands of the upper Mississippi Valley; P. m. osgoodi occurs in the dry sagebrush regions of the west; $P$. $m$. rufinus inhabits the forested regions of the Rocky Mountains; $P$. m. artemisiae occupies the forested areas of the northwest, while $P$. $m$. blandus lives in the dry desert regions of the southwest. It might be expected that these differences in habitat requirements would have some effect upon the physiology of the reproductive processes and perhaps show this by a difference in the gestation periods. When the means of the gestation periods of these subspecies are compared, however, they are found to be very similar.

It may be argued that keeping the mice in the laboratory under uniform conditions may have brought about the similarity. Sumner (1924) has shown that subspecies of deermice retain their morphological characteristics regardless of uniform laboratory conditions. It is generally assumed that through the ages, the reproductive processes have been least changed of all the physiological processes characteristic of animals, and it appears that such fundamental physiological characters as the lengths of gestation are not modified by short exposure to environmental change.

\section{Relation of Geographical Range to Period of Gestation}

No correlation between geographical distribution and gestation periods has been found. P. m. blandus, which is native to such southwestern states as New Mexico, Arizona, and California as well as to Mexico, has the same mean length of gestation as $P . m$. artemisiae and $P . m$. osgoodi, which occur in Montana, Wyoming, Oregon, and British Columbia. The mean gestation periods for the subspecies of $P$. leucopus . were not appreciably different from each other although they came from distant localities in Missouri, Ohio, and Michigan.

\section{Relation of Size to Period of Gestation}

It is generally assumed that the larger the animal, the longer the gestation period. That size of the adult is no criterion for the length of gesta- 
tion within the genus Peromyscus, is evidenced by the fact that $P$. californicus, which is the largest mouse studied, had the same mean gestation period as $P$. maniculatus and $P$. leucopus which are the smallest. This also holds true for the subspecies of the different species.

\section{Condition of the Young at Birth}

The wrinkled and bright flesh colored appearance of the newly born young in all the subspecies of $P$. maniculatus is very much alike. The skin, especially on the ventral surface, is very thin and semi-transparent, so that the ribs and milk, when the latter is present in the stomach, are clearly visible. Except for the vibrissae, which are already formed and about three millimeters in length, the skin appears to the naked eye to be hairless. Microscopic sections of the skin of the newly born young show that the hairs have already pushed through the outermost layer of skin. Hence the term "naked" which is, in general, applied to these newly born mice, is not strictly correct.

Newly born mice have the eyes closed, although the future eye slit is present as a shallow groove. The iris of the eye appears through the semitransparent skin as a dark ring. The pupil is a pink dot in the center of the iris.

The pinna of the ear is folded down flat against the lower portion of the ear, thus covering the otic orifice.

The toes with the claws are already formed. They have not yet divided into separate digits but are still held together by the interdigital membrane which extends along the entire length of the digit.

Within 24 hours after birth, the dorsal region of the body becomes darkly pigmented, due to the deposition of pigment granules in the medulla of the developing hairs. The young of P. leucopus, irrespective of the subspecies, are born in the same condition as young $P$. maniculatus. They are also flesh-colored, and the dorsal area becomes darkly pigmented within 24 hours after birth. In $P$. truei the young are likewise born flesh-colored, similar to the other species of the subgenus Peromyscus, and within 24 hours, they, too, become darkly pigmented on the dorsal surface. The condition of the young of these three species in the subgenus Peromyscus is very similar at birth.

The young mice of the subgenus Haplomylomys differ from those of the subgenus Peromyscus. In $P$. californicus the young are born in a more developed state than are the young of $P$. maniculatus, $P$. leucopus, or $P$. truei. Instead of being flesh-colored, they are born with the dorsal region already darkly pigmented. The young of $P$. eremicus are very similar to those of $P$. californicus. 
The pinna of the ear unfolds in less than 24 hours in the subgenus Haplomylomys, whereas 3 days are required in the subgenus Peromyscus for this to take place.

The observed differences in the condition of the young of these two subgenera at birth are summarized in Table IV.

TABLE IV

YOUNG OF PEROMYSCUS

\begin{tabular}{|c|c|c|}
\hline & Color at Birth & $\begin{array}{l}\text { Time for Unfolding } \\
\text { Pinna of Ear }\end{array}$ \\
\hline \multicolumn{3}{|l|}{ Subgenus Peromyscus } \\
\hline 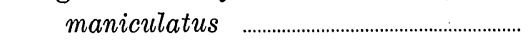 & pink & 3 days \\
\hline 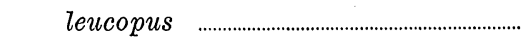 & 66 & $66 \quad 66$ \\
\hline truei & 6 & 66 6 \\
\hline \multicolumn{3}{|l|}{ Subgenus Haplomylomys } \\
\hline 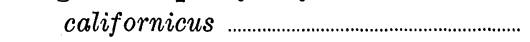 & dorsally-pigmented & less than 24 hours \\
\hline \multirow{2}{*}{ 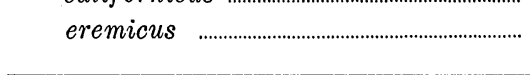 } & 66 & 666666 \\
\hline & $\cdot$ & \\
\hline
\end{tabular}

\section{LITTER SIZE}

It has been stated (Osgood, 1909; Nelson, 1918) that deermice usually have from 3 to 9 young in a litter. This information is based upon the number of embryos found in pregnant females by field collectors. Scheffer (1924) collected a series of 48 pregnant females of Peromyscus ${ }_{i}($ Peromyscus) gambelii from Washington and found that the number of embryos varied from 3 to 9 , with 5 as the average as well as the number of greatest frequency.

It is well known that the number of embryos is often greater than the number of young actually born. Hence, in this study, litter size is based upon the number of young found immediately after birth. Examination of the mice twice daily made it possible to determine the number of young in a litter very closely (within a maximum period of 12 hours) after birth. It was found that unless a female is greatly disturbed, she seldom kills her young at birth. Only on one occasion did a female destroy her young without apparent provocation. This female was conspicuously gravid up to the night before she was expected to have young. The following morning, it was evident by her appearance that the young had been born but apparently destroyed.

In this study, 292 litters of deermice were examined. These were distributed among the various species and subspecies as shown in Table V.

In $P$. maniculatus, as a whole, the litters ranged in size from 1 to 9 . In general, each subspecies also varied within this range. The mice of this 
species, and in fact this subgenus, have but 6 mammae. In spite of this, several litters of 7 mice were raised to maturity. The young mice evidently took turns in nursing. Hence, the number of mammae is not always a true index of the maximum number of young that can be born or raised.

The number of young per litter in $P$. leucopus varied from 1 to 6 . The subspecific variations in litter size also fell within these limits.

It was found that there are indications that some females regularly produce larger litters than others. For instance, a female $P$. m. osgoodi (no. 6020) gave birth to 4 litters of 7, 9, 7, and 4 young; another female P. m. osgoodi (no. 4854) produced 4 litters of $3,3,5$, and 2 young; a female $P$. m. blandus (no. 3283) had 4 litters of 3, 1, 3, and 1 young; another female $P . m$. blandus (no. 1936) had 7 litters of 4, 6, 4, 6, 6, 6, and 4 young. In $P$. leucopus, a similar individuality exists. Female $P$. $l$. noveboracensis (no. 3790) produced 5 litters of 5 young each; female no. 6178 had. 4 litters of $3,4,4$, and 4 young.

The litter size in $P$. truei varied from 2 to 5 in a total of 19 litters. Five young in a litter occurred but once while 2 occurred 7 times, producing a mean of 2.84 young. This shows another specific character difference between this species and both $P$. maniculatus and $P$. leucopus. It has been shown that the two latter species, in regard to the period of gestation and the weight of the young at birth, are more similar to each other than they are to $P$. truei. They are also more similar to each other in regard to litter size than they are to $P$. truei in spite of the fact that a certain amount of overlapping occurs.

The litter size in $P$. (Haplomylomys) californicus ranged from 1 to 3 in a total of 15 litters, thus showing a mean of 1.87 young. The small litter size in this species is conspicuous in comparison with that of $P$. maniculatus and $P$. leucopus, and to a less degree with that of $P$.truei. It is interesting to note that in this species there are but four mammae, which are located in the inguinal region. This important characteristic may have some correlation with the relatively small number of young produced in a litter.

$P$. (Haplomylomys) eremicus likewise has a small number of young per litter. In 5 litters the number varied from 2 to 3 with a mean of 2.6. As in $P$. californicus, this species also has but 4 inguinal mammae. These two species in this subgenus are distinct from the members of the subgenus Peromyscus in regard to litter size as well as those morphological characters which distinguish them as separate subgenera.

The conclusion may be drawn that in regard to litter size, $P$. maniculatus and $P$. leucopus resemble each other closely, whereas $P$. truei differs from these two species. In any one species, the litter size of its component subspecies is very similar. $P$. californicus and $P$. eremicus both produce but 
few young in a litter, differing in this physiological characteristic from the subgenus Peromyscus but agreeing closely with each other.

TABLE V

LITTER SIZE OF PEROMYSCUS

\begin{tabular}{|c|c|c|c|}
\hline & Litters & $\begin{array}{l}\text { Number of } \\
\text { Young }\end{array}$ & Mean \\
\hline \multicolumn{4}{|l|}{ Peromyscus (Peromyscus) maniculatus } \\
\hline artemisiae & 42 & $1-7$ & $4.43 \pm .18$ \\
\hline bairdii & 21 & $1-6$ & $3.05 \pm .20$ \\
\hline 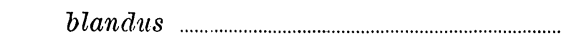 & 40 & $1-6$ & $3.83 \pm .16$ \\
\hline gambelii & 5 & $3-4$ & $3.20 \pm .12$ \\
\hline osgoodi & 44 & $1-9$ & $4.59 \pm .18$ \\
\hline 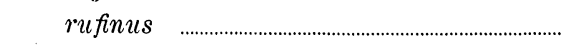 & 27 & $1-8$ & $4.26 \pm .18$ \\
\hline 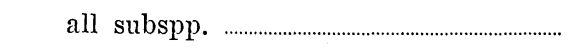 & 179 & $1-9$ & $4.04 \pm .03$ \\
\hline \multicolumn{4}{|l|}{ Peromyscus (Peromyscus) leucopus } \\
\hline leucopus & 21 & $1-5$ & $3.43 \pm .13$ \\
\hline 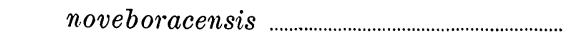 & 53 & $1-6$ & $4.36 \pm .10$ \\
\hline 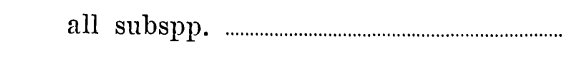 & 74 & $1-6$ & $4.09 \pm .08$ \\
\hline \multicolumn{4}{|l|}{ Peromyscus (Peromyscus) truei } \\
\hline 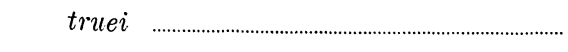 & 19 & $2-5$ & $2.84 \pm .14$ \\
\hline \multicolumn{4}{|l|}{ Peromyscus (Haplomylomys) californicus } \\
\hline californicus & 15 & $1-3$ & $1.87 \pm .09$ \\
\hline \multicolumn{4}{|l|}{ Peromyscus (Haplomylomys) eremicus } \\
\hline eremicus …….......................................... & 5 & $2-4$ & $2.60 \pm .24$ \\
\hline
\end{tabular}

\section{Weights of the Young at Birth}

The weights at birth of 455 young deermice were ascertained. The observations were distributed among the 5 species as shown in the accompanying table (Table VI).

In Peromyscus (Peromyscus) maniculatus the weights at birth varied from 1.1 to 2.3 grams with a specific mean of 1.72 grams. Within each of the subspecies practically the same variation occurred. The young of the same litter often varied considerably as to weight. For instance, a litter of 5 in $P$. m. rufinus ranged from 1.4 to 2.0 grams; in $P$. m. bairdii, a litter of 4 varied from 1.1 to 1.6 grams. In a few litters, the birth weights were constant, as for example, a female of $P$. $m$. artemisiae, gave birth to 4 young, each of which weighed 1.9 grams. Variations of a few tenths of a gram within a litter occurred most commonly. Within the subspecies, and 
even among the litters of the same mother, the average weights of individual young in litters of 7 may be either less or greater than in litters of 3 .

The means of the various subspecies in this species showed no significant differences. Size of the adult, ecological preferences, and distribution had no apparent effect upon the birth weights in this species. As a whole the birth weights in this species showed a marked uniformity, indicating again a physiological as well as a morphological homogeneity.

In Peromyscus (Peromyscus) leucopus, a total of 114 young were weighed at birth. Of these, 16 were in the subspecies $P$. l. leucopus and 98 in the subspecies $P$. $l$. noveboracensis. Within the species, the birth weights varied from 1.4 to 2.4 grams with a mean of 1.87 grams. Practically the same variation was found within each of the subspecies. Variation in the weights of the young in the same litter also occurred. No significant difference in the means of the two subspecies was evident. Thus, $P$. leucopus as a whole exhibits a physiological as well as a morphological uniformity.

It will be noted that a close similarity exists between the specific birth weight mean for $P$. leucopus and for $P$. maniculatus. This points to a close physiological relationship between the two species which parallels their morphological similarity.

Twenty-one young of $P$. (Peromyscus) truei were weighed at birth. The weights varied from 1.7 to 3.0 grams with a mean of 2.31 grams. The weights of the young of the same litter also varied as much.

Comparing the mean weights of this species with those of $P$. maniculatus (1.72 grams) and P. leucopus (1.87 grams), it will be noted that the means for the two latter species show greater similarity to each other than they do to the mean for $P$. true $i$ which is greater (2.31 grams).

In Peromyscus (Haplomylomys) californicus, the birth weights of 19 mice were secured. These varied from 3.6 to 5.8 grams, with a mean of 4.92 grams. As in the other species, the weights of the young of one litter also varied.

A very marked difference is seen in the weight at birth of these mice and those of the subgenus Peromyscus. The young of this species weigh about three times as much as the young of $P$. maniculatus and $P$. leucopus and twice as much as the young of $P$. truei.

The weights of 9 young were obtained in $P$. (Haplomylomys) eremicus. There was a variation of from 2.1 to 2.9 grams with a mean of 2.54 grams.

Compared with $P$. californicus, the means differed considerably (4.92 grams for $P$. californicus and 2.54 grams for $P$. eremicus). The difference between the means for $P$. eremicus and $P$. true $i$ is slight (2.54 grams and 2.31 grams respectively), indicating a close similarity. The difference 
in adult weights of these two species is more pronounced. $P$. truei is a much heavier mouse than $P$. eremicus, showing that the differences in their birth weights are really an indication of more distant relationship.

In summary then, the subspecies of the species $P$. maniculatus showed a uniformity in the weights of the young at birth. The same is true of the subspecies of $P$. leucopus. These two species did not differ significantly from each other in regard to the weights of the young at birth.

The young of $P$. truei were heavier than the young of $P$. maniculatus and $P$. leucopus, showing a gap between $P$. truei and these two species.

The young of $P$. californicus were the heaviest at birth, as might be expected, for it is the largest deermouse in the United States.

The young of $P$. eremicus were also heavier than the young of any of the mice of the subgenus Peromyscus, although the adult weight of this species is not as great as the adult weight of the largest member of the subgenus Peromyscus, i.e., P. truei. There is a subgeneric difference in the weights

TABLE VI

WEIGHT OF PEROMYSCUS AT BIRTH

\begin{tabular}{|c|c|c|c|c|}
\hline \multirow{2}{*}{ Subspp. } & \multirow{2}{*}{ Number } & Lowest & Highest & Mean \\
\hline & & \multicolumn{2}{|c|}{ Grams } & Grams \\
\hline \multicolumn{5}{|l|}{ Peromyscus (Peromyscus) maniculatus } \\
\hline artemisiae & 70 & 1.3 & 2.0 & $1.71 \pm .11$ \\
\hline 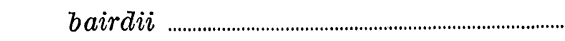 & 23 & 1.1 & 2.3 & $1.67 \pm .41$ \\
\hline 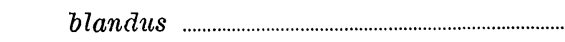 & 22 & 1.5 & 2.1 & $1.80 \pm .20$ \\
\hline 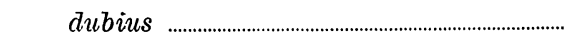 & 12 & 1.5 & 2.4 & $1.97 \pm .48$ \\
\hline 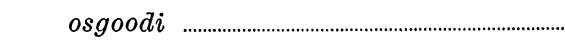 & 121 & .8 & 2.0 & $1.72 \pm .12$ \\
\hline 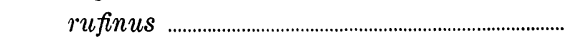 & 44 & 1.3 & 2.0 & $1.67 \pm .20$ \\
\hline all subspp. & 292 & .8 & 2.4 & $1.72 \pm .08$ \\
\hline \multicolumn{5}{|l|}{ Peromyscus (Peromyscus) leucopus } \\
\hline leucopus & 16 & 1.5 & 2.4 & $1.85 \pm .42$ \\
\hline 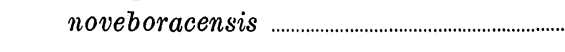 & 98 & 1.4 & 2.4 & $1.87 \pm .13$ \\
\hline 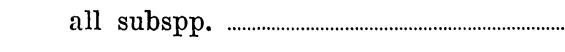 & 114 & 1.4 & 2.4 & $1.87 \pm .03$ \\
\hline \multicolumn{5}{|l|}{ Peromyscus (Peromyscus) truei } \\
\hline truei & 21 & 1.7 & 3.0 & $2.31 \pm .42$ \\
\hline \multicolumn{5}{|l|}{ Peromyscus (Haplomylomys) californicus } \\
\hline 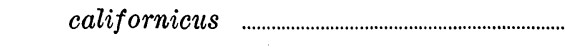 & 19 & 3.6 & 5.8 & $4.92 \pm .78$ \\
\hline \multicolumn{5}{|l|}{ Peromyscus (Haplomylomys) eremicus } \\
\hline eremicus & 9 & 2.1 & 2.9 & $2.54 \pm .65$ \\
\hline
\end{tabular}


of the young at birth, those of the subgenus Haplomylomys being heavier than those of the subgenus Peromyscus.

\section{Age of Young when Eyes Open}

Observations on a total of 86 litters of deermice afforded data on the time necessary for the eyes to open (see Table VII).

In 47 litters of $P$. maniculatus, the eyes of the young opened when they were from 12 to 17 days old. Practically the same extremes hold for the various subspecies. As a general rule, the eyes opened on the fourteenth day after birth. Within the same litter, there was often a variation of several hours.

In 28 litters of $P$. leucopus, the eyes opened from 10 to 15 days after birth, with a mean for the species of 13.36 days. The means for the two subspecies, $P$. $l$. leucopus and $P$. $l$. noveboracensis, are practically the same. Compared with $P$. maniculatus, the eyes open 1 day younger.

In 3 litters of $P$. truei, the eyes opened from 15 to 20 days after birth. In the single instance of the 20-day litter, the female was extremely nervous

TABLE VII

AGE OF YंOUNG PEROMY'SCUS WHEN EYES OPEN

\begin{tabular}{|c|c|c|c|}
\hline Subspp. & Litters & Age in Days & Mean Age \\
\hline \multicolumn{4}{|l|}{ Peromyscus (Peromyscus) maniculatus } \\
\hline artemisiae & 6 & $13-16$ & $14.50 \pm .26$ \\
\hline 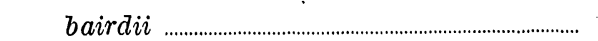 & 6 & $12-16$ & $13.67 \pm .38$ \\
\hline 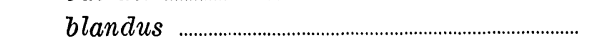 & 11 & $13-16$ & $14.36 \pm .16$ \\
\hline 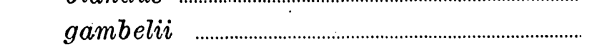 & 3 & $12-15$ & $13.33 \pm .49$ \\
\hline 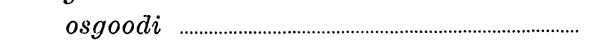 & 13 & $12-17$ & $13.69 \pm .29$ \\
\hline 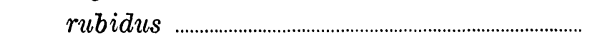 & 1 & $15-15$ & 15.00 \\
\hline 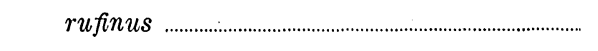 & 7 & $14-17$ & $15.14 \pm .25$ \\
\hline 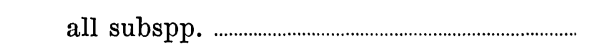 & 47 & $12-17$ & $14.20 \pm .13$ \\
\hline \multicolumn{4}{|l|}{ Peromyscus (Peromyscus) leucopus } \\
\hline 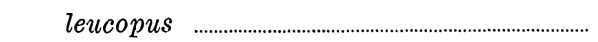 & 8 & $12-15$ & $13.13 \pm .25$ \\
\hline 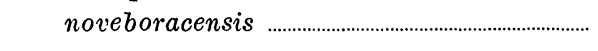 & 20 & $10-15$ & $13.45 \pm .18$ \\
\hline 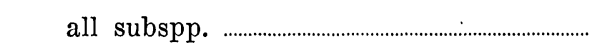 & 28 & $10-15$ & $13.36 \pm .10$ \\
\hline \multicolumn{4}{|l|}{ Peromyscus (Peromyscus) truei } \\
\hline 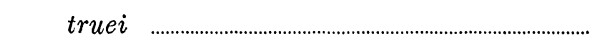 & 4 & $15-20$ & $17.50 \pm .69$ \\
\hline \multicolumn{4}{|l|}{ Peromyscus (Haplomylomys) californicus } \\
\hline californicus …………………………………………........ & 3 & $13-14$ & $13.67 \pm .16$ \\
\hline \multicolumn{4}{|l|}{ Peromyscus (Haplomylomys) eremicus } \\
\hline 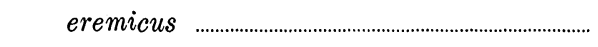 & 4 & $15-17$ & $15.50 \pm .30$ \\
\hline
\end{tabular}


during the nursing period and left her young whenever any one came near the nest. This probably interfered with the nourishment of the young. Such conditions may influence the time required for the eyes to open. This same possible source of error applies to published observations on red squirrels (R. D. Svihla, 1930).

In 3 instances, the young of $P$. (Haplomylomys) californicus opened their eyes when they were from 13 to 15 days old. In 2 instances, the eyes opened on the fourteenth day. Although the number of litters observed is insufficient for statistical use, nevertheless there appears to be a striking similarity to the condition found in $P$. maniculatus and $P$. leucopus, both of which differ markedly from $P$. californicus in the condition of the young at birth.

In 4 litters of $P$. (Haplomylomys) eremicus, the eyes opened from 15 to 17 days after birth, 3 litters in 15 days, and 1 in 17 days. Too few litters were available for the data to be considered statistically significant.

The age of the young when the eyes open is nearly the same in all the subspecies of $P$. maniculatus, thus showing a specific uniformity in this regard. A similar condition holds true for the subspecies of $P$. leucopus. A significant difference of one day exists between the ages of the young when the eyes open in.P. maniculatus and $P$. leucopus. Available data for $P$. truei, $P$. californicus, and $P$. eremicus were insufficient for statistical use. The data obtained showed no difference from those secured for $P$. maniculatus.

\section{Age of Young When Weaned}

All of the species of deermice are born in a very immature condition, and therefore for a period after birth they are unable to care for themselves. During this early period, the hair and teeth appear, coördinated movements develop, and the eyes and ears open. The period of dependency lasts until the young are weaned. As soon as their eyes open, they begin to eat solid food, although they still obtain supplementary nourishment from the mother. Weaning is usually a gradual process but may be terminated very abruptly upon the arrival of another litter. At this time, the mother usually refuses to suckle the first litter and forces them out of the nest. Occasionally, young of both litters have been observed to nurse together for a few days. Should no second litter arrive, the young of the first litter nurse for a longer time.

The young of $P$. maniculatus and $P$. leucopus have been weaned in as short a time as 22 days. The longest time of suckling recorded was 37 days.

In $P$. truei, a longer period of nursing is necessary. Development is evidently slower than for the young of $P$. maniculatus and $P$. leucopus, 
for, if the young are removed from the mother before they are a month old, they seldom survive. One litter was not weaned until 40 days old.

In $P$. nuttalli, a single instance was observed in which a second litter was born before the first litter was fully weaned. The young of the first litter were unable to maintain themselves and died.

In $P$. californicus and $P$. eremicus the period of nursing is always prolonged; since these mice are not in heat immediately after parturition, the second litter does not arrive to compete with the first. One litter of $P$. californicus was not weaned until 44 days after birth.

\section{ProLIFICNESS}

Like many other small rodents, deermice are very prolifie and occur abundantly throughout their general ranges. $P$. maniculatus produces litters of young in rapid succession. Assuming that the mean gestation period is 23 days, 15 litters would be the maximum number one female could produce in one year. If the average size of the litter were 4 , then 60 young could be born during this time. This number could be born only if some of the young were destroyed at birth, for if all the young were allowed to suckle, fewer litters per annum would result, due to the lengthening effect of lactation upon some of the gestations. A more typical length of gestation is 25 days, the mean of the extremes of gestation. One female could produce and raise 14 litters per year, a total of 56 mice. In the Murarium one female gave birth during one year to 11 litters with 42 young. This was the nearest approach to the possible maximum number.

The mice of the species $P$. leucopus are likewise very prolific. Records of 10 litters during one year for one female are also known for this species. One female produced 45 young in a year's time. Other records are given in Table VIII.

In $P$. truei, as has been previously shown, the mean litter size is smaller than it is for either $P$. maniculatus or P. leucopus. The length of gestation is longer for $P$. true $i$ than for these other two species. As a rule, $P$. truei also bred less frequently and less readily in the laboratory. More litters were produced during the summer months than during the winter. These factors tend to reduce prolificness in the species.

The mice of the subgenus Haplomylomys were found to be very uncertain breeders. Some females reproduced fairly rapidly while others did not breed at all. These mice were, on the whole, the least prolific of all those studied.

Some females of the species $P$. californicus have had as many as 6 litters per year, but as the usual number of young per litter is 2 , the total number of young produced in a year, or 12, is much less than the number produced by $P$. maniculatus or P. leucopus. 
TABLE VIII

SELECTED EXAMPLES OF THE PROLIFICNESS OF FEMALES OF PEROMYSCUS DURING ONE YEAR

\begin{tabular}{|c|c|c|c|c|}
\hline Subspp. & Labo & atory Number & Young & Litters \\
\hline \multicolumn{5}{|c|}{ Peromyscus maniculatus } \\
\hline \multirow{2}{*}{$\underset{6}{\operatorname{artemisiae}}$} & (1) & 4547 & 15 & 4 \\
\hline & & 3425 & 30 & 6 \\
\hline \multirow{2}{*}{ 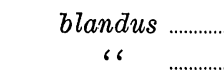 } & 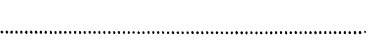 & 1936 & 36 & 7 \\
\hline & & 1937 & 19 & 5 \\
\hline \multirow{2}{*}{$\underset{6}{\text { rufinus }}}$. & $\ldots \ldots \ldots . .$. & 4265 & 30 & 8 \\
\hline & $\ldots \ldots \ldots \ldots$ & 4361 & 30 & 7 \\
\hline \multirow{2}{*}{$\underset{6}{\text { osgoodi }}$} & (1) - (- & 6020 & 27 & 4 \\
\hline & (1) & 4128 & 26 & 7 \\
\hline \multicolumn{5}{|c|}{ Peromyscus leucopus } \\
\hline \multirow{2}{*}{\multicolumn{2}{|c|}{$\begin{array}{c}\text { noveboracensis } \\
\text {,.. }\end{array}$}} & 6193 & 25 & 5 \\
\hline & $\ldots \ldots \ldots .$. & 3790 & 25 & 5 \\
\hline \multicolumn{2}{|c|}{ 6 } & 4880 & 24 & 6 \\
\hline \multicolumn{2}{|c|}{$\begin{array}{c}\text { leucopus } \\
\text { 6 }\end{array}$} & 1985 & 16 & 4 \\
\hline $6 \quad \ldots \ldots$ & (n) & 1990 & 23 & 6 \\
\hline \multicolumn{5}{|l|}{ Peromyscus truei } \\
\hline \multicolumn{2}{|l|}{ truei } & 4747 & 8 & 3 \\
\hline 6 & 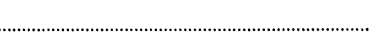 & 1409 & 26 & 7 \\
\hline \multirow{2}{*}{$\begin{array}{ll}6 & \ldots \\
6 & \ldots\end{array}$} & (1) & 1402 & 15 & 5 \\
\hline & 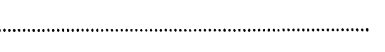 & 889 & 18 & 5 \\
\hline \multicolumn{5}{|c|}{ Peromyscus californicus } \\
\hline \multirow{2}{*}{$\underset{6}{\text { californicus }}$} & (1) & 1756 & 10 & 5 \\
\hline & 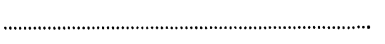 & 4566 & 11 & 6 \\
\hline
\end{tabular}

$P$. eremicus is similar to $P$. californicus in being a slow breeder. The number of young per litter is also small, so that the reproductive rate per year is likewise small. One female, number 4426, produced 6 young in 3 litters during one year.

In summary, $P$. maniculatus and $P$. leucopus are the most prolific of the deermice observed, while $P$. truei, $P$. californicus, and $P$. eremicus are respectively less prolific.

This difference in prolificness may have had some influence upon the distributions of these mice. The more prolific species, $P$. maniculatus and $P$. leucopus, are widely dispersed over the North American continent, whereas $P$. truei, $P$. californicus, and $P$. eremicus, which are less prolific, are found in more restricted areas. It is logical to believe that the more prolific species are able to compete more successfully for a habitat than the less prolific. Prolificness tends to insure the continuation of the species through main- 
tenance of numbers, despite depredations of disease, climatic adversities, and predatory animals.

\section{Correlation between Physiological and Morphological Characters}

It is a general assumption that the larger the animal, the larger and fewer the young at birth and the longer the gestation period. This is true in a general way when such diverse animals as cows and mice are considered, but does not always hold true in particular comparisons.

Peromyscus $m$. bairdii is much smaller in body measurements and weight than $P$. m. artemisiae, consequently one would expect $P$. m. bairdii to have a shorter gestation period and produce more and smaller young than $P$. $m$. artemisiae. On the contrary, the length of periods of gestation, the number of young, and the weights of the young at birth for these two species are the same.

Peromyscus truei is slightly larger than either $P$. maniculatus or $P$. leucopus, and it has a longer gestation period and produces fewer and heavier young than either of these species.

Peromyscus californicus is at least twice as large as $P$. maniculatus. These two species have the same length of gestation, although $P$. californicus produces fewer and heavier young than $P$. maniculatus. $P$. eremicus is about the same size as $P$. maniculatus, but like $P$. californicus produces fewer and heavier young.

Within the genus Peromyscus it is therefore evident that there is no important correlation between the size of the mouse and the length of gestation, litter size, or the condition of the young at birth.

As Osgood (1909) has shown, the subgenera Haplomylomys and Peromyscus are separable by a difference in dental characters. Accessory tubercles are present in the outer angles of $m 1$ and $m 2$ in the subgenus Peromyscus and absent in Haplomylomys. These dental characters are considered of greater phylogenetic significance, because of their supposedly more fundamental nature, than the proportional differences in measurements. Another morphological character that distinguishes these two subgenera is the number of mammae. Two pairs of inguinal teats are present in Haplomylomys and three pair, two inguinal and one pectoral, in Peromyscus.

The relative difference in size, a character which commonly separates species, is used to distinguish species in both subgenera.

In the subgenus Haplomylomys, $P$. californicus is larger than $P$. eremicus. $P$. californicus may be said to be a large $P$. eremicus, for in all its proportions it is uniformly larger, with no accentuation in size of one part of the body at the expense of another.

In the subgenus Peromyscus, the species $P$. maniculatus, $P$. leucopus, and $P$. truei are also distinguished from each other by differences in body 
measurements (see Osgood, 1909) and in the two former species, in color pattern and degree of hairiness of the tail. P. truei differs from and is readily distinguished from either $P$. maniculatus or $P$. leucopus by its larger body size, its much larger ears, and its longer tail. There is not the same uniformity of proportions between $P$. true $i$ and $P$. maniculatus or $P$. leucopus that there is between $P$. californicus and $P$. eremicus, since $P$. true $i$ has disproportionately larger ears. This, perhaps, indicates that this species has diverged from $P$. maniculatus and $P$. leucopus for a longer time than has $P$. californicus from $P$. eremicus.

Peromyscus maniculatus and $P$. leucopus are not so easily separated because they resemble each other very closely in all body characters. They are known to differ from each other only in degrees of hairiness and color pattern of the tail. The tail of $P$. maniculatus is more hairy and more sharply bicolored than that of $P$. leucopus. The characters separating these two species are not so definite nor as clear-cut as the characters which separate them from $P$. truei.

The subspecies within the species in Peromyscus are distinguished from each other with difficulty. Combinations of various characters such as color, proportion of tail length to body length, relative sizes of ear and hind foot, are used to distinguish them (see Osgood, 1909). Geographical dis. tribution is also important in the final interpretation of a subspecies. These statements apply to the separation of the subspecies of $P$. leucopus as well as those of $P$. maniculatus.

Throughout this study the question of correlating the physiological and morphological characters has been kept in mind with the idea of presenting actual data to substantiate or refute the validity of the taxonomic divisions of the genus Peromyscus.

When certain of the physiological processes of these mice, such as those presented in the preceding pages, are considered in their relation to the taxonomic divisions of the genus, it will be seen that those mice which are closely related taxonomically (as' indicated by their similar morphology) also show a great many similarities in regard to the reproductive processes. The mice more distantly related taxonomically have fewer reproductive similarities. It may be stated that the species with many similar morphological characters are closely related, and it will be found that they will also have a great many similarities in regard to their processes of reproduction.

A more detailed comparison of these two types of characters, in relation to the taxonomic divisions in the genus Peromyscus, follows.

A high degree of similarity is clearly seen when the reproductive processes of mice in one group of subspecies are compared. In P. maniculatus, for instance, all of the subspecies reveal practically the same reproductive phenomena, having similar gestation periods, a like condition of the young 
at birth, similar weights of the young at birth, a similar number of young per litter, and a similar age when their eyes open and when they are weaned. A like similarity exists in regard to the physiological processes of reproduction among the component subspecies of $P$. leucopus. Groups of subspecies show a decided specific unity in reproductive processes just as they do in morphological characters.

The morphological differences between P. leucopus and P. maniculatus are relatively slight. Their taxonomic relationships are judged to be correspondingly close. It has been shown above that these two species are also closely allied in respect to certain reproductive phenomena. This substantiates the conclusion based upon morphological characters that these two species have a very close relationship.

As has been previously mentioned, the differences in morphological characters separating $P$. truei from either $P$. maniculatus or $P$. leucopus are more marked than those separating these two latter species from each other. This suggests that $P$. true $i$ is more distantly related to both these species than they are to each other. When the same features of reproduction in $P$. truei and in P. maniculatus or P. leucopus are compared, great differences will also be noted between them substantiating the conclusion that they are more distantly related.

The few reproductive similarities, such as the condition of the young at birth, which characterize the three species just named, may be regarded as of subgeneric rather than merely specific significance because of their simultaneous occurrence in all these species. These characters would then be of equivalent value to the structural subgeneric characters such as the presence of accessory tubercles.

As stated above, $P$. californicus and $P$. eremicus differ from each other in size although the proportions of the measurements of the two are practically the same. These two species also have been found to differ in regard to some physiological processes of reproduction. They also have a number of similarities in these processes, for instance the periods of gestation and the condition of the young at birth were found to be practically the same. The greatest difference in reproduction between these two forms exists in the weights of the young at birth. There are lesser differences in the number of young in a litter and the age of the young before the eyes open. On account of the number of similarities in reproductive physiology it appears then that these two species are closely related. Since it has been shown that these two species are similar in morphological proportions, their physiological similarities may be interpreted as substantiating their close relationship.

It has also been shown that the species of the subgenus Peromyscus resemble each other in regard to the condition of the young at birth and that 
this character may be of subgeneric value. In the subgenus Haplomylomys, the young of both species are alike at birth, and differ from the young of the subgenus Peromyscus. A lack of pigmentation is very characteristic of the young of the subgenus Peromyscus, whereas pigmentation of the young is just as characteristic of the young of the subgenus Haplomylomys. This significant difference between the subgenera in the condition of the young at birth, may prove to be as important in separating these two subgenera as the number of mammae or the presence of accessory tubercles in the molars.

In conclusion, it may be stated that the degree of relationship between two species is shown by the number of similarities in physiological functions as well as in morphological characters. The more closely related taxonomic groups show close similarities in respect to their morphological and reproductive characters, whereas, the more distantly related taxonomic groups show correspondingly greater differences.

\section{Summary}

The period of gestation, condition of the young at birth, the weight of the young at birth, the number of young in a litter, the age of the young at the time the eyes open, the age of the young when weaned, and the possible number of litters per year, have been ascertained for various species and subspecies of Peromyscus.

The gestation period varies from 21 to 40 days.

Lactation influences the period of gestation by prolonging it. The gestation periods of non-lactating females are of chief value in this comparative study.

Habitat requirements, distribution, the number of young in a litter, and the size of the adult have no apparent effect upon the length of gestation.

There is apparently a subgeneric difference in the condition of the young at birth.

The weight of the young at birth varies from 0.8 to 5.8 grams. A specific difference in this character was found. The larger species of these mice produce the heavier young.

From one to nine young are produced in a litter. The smaller species produce more young for a litter than do the larger. A subgeneric difference was established in regard to this characteristic.

The eyes of the young opened from 10 to 20 days after birth. Slight specific differences were noted in this respect.

The maximum number of litters per year is calculated to be 15 . Several females in the subgenus Peromyscus had records of 10 and 11 litters for one year. The larger mice of the subgenus Haplomylomys produce fewer litters and fewer young per year. 
Differences and similarities among the various taxonomic groups of Peromyscus in regard to these reproductive processes are as follows :

The subspecies of $P$. maniculatus are similar to one another in respect to the gestation period, condition of the young at birth, weights of the young at birth, number of young in a litter, and age of the young when the eyes open. The subspecies of $P$. leucopus are likewise similar to one another.

The species $P$. maniculatus and $P$. leucopus are similar in regard to the gestation period, condition of the young at birth, size of the litter, weights at birth, age of the young when weaned, and in prolificness. They differ slightly in respect to the age when the young have their eyes open.

$P$. truei differs from $P$. maniculatus and $P$. leucopus in all of the reproductive processes studied except the condition of the young at birth.

$P$. truei also differs from $P$. maniculatus and $P$. leucopus in many morphological characters.

In the subgenus Haplomylomys, $P$. californicus is very similar to $P$. eremicus in the reproductive processes studied.

The subgenus Haplomylomys differs from the subgenus Peromyscus in all the reproductive processes studied except the period of gestation and, to some extent, the age of the young when the eyes open.

It may therefore be stated that physiological differences and similarities in the reproductive processes of Peromyscus are correlated with the morphological differences and similarities of the various taxonomic divisions of the genus. The more closely related taxonomic groups show close similarities in respect to their morphological and reproductive characters, whereas, the more distantly related taxonomic groups show correspondingly greater differences.

In summary, it may be stated that the data here presented in reference to the life histories of the mice of the genus Peromyscus support the general thesis that physiological functions are correlated with morphological characters and that both of these may be used in determining taxonomic groupings.

ALLEN, EDGAR

\section{Literature Cited}

1922. The Oestrous Cycle in the Mouse. Amer. Jour. Anat., 30: 301.

ALLEN, L. M.

1907. Prolonged Gestation. Amer. Jour. Obstetrics, 55: 541-549.

BAILEY, VERNON

1924. Breeding, Feeding, and Other Life Habits of Meadow Mice (Microtus). Jour. Agric. Research, 27 : 523-536.

DANIEL, J. F.

1910. Observations on the Period of Gestation in White Mice. Jour. Exper. Zool., 9 : 865-870. 
DarWin, Chas.

1875. The Variation of Plants and Animals Under Domestication. D. Appleton \& Co., New York (1896 Ed.), 1: 31-77, 101.

DICE, L. R.

1929. A New Laboratory Cage for Small Mammals, with Notes on Methods of Rearing Peromyscus. Jour. Mamm., 10: 116-124.

Franck, J. L., Albrecht, M., and Göring, Ph.

1901. Die Trächtigkeitsdauer. Thierärztliche Geburtshülfe, 4: 153-159.

HALL, E. R.

1928. Note on the Life History of the Woodland Deer Mouse. Jour. Mamm., 9 : 255-256.

HAMmond, J., and Asdell, J. A.

1926. The Vitality of the Spermatozoa in the Male and Female Reproductive Tracts. Brit. Jour. Exper. Biol., 4 : 155-185.

HARRIS, J. A.

1916. Studies on the Correlation of Morphological and Physiological Characters. Genetics, 1: 185 .

Harris; J. A., Blakeslee, A., and Warner, D.

1917. The Correlation of Body Pigmentation and Egg Laying in the Domestic Fowl. Genetics, 2: 36.

HEINRICH, C.

1923. Revision of the North American Moths of the Subfamily Eucosminae of the Family Olethreutidae. U. S. Nat. Mus. Bull., 123: 298.

HowelL, W. H.

1927. Textbook of Physiology. W. B. Saunders Co., Philadelphia: 1081.

KING, H. D.

1913. Some Anomalies in the Gestation of the Albino Rat (Mus norvegicus albinus).

KIRKHAM, W. B.

Biol. Bull., 24: 377-391.

1916. The Prolonged Gestation Period in Suckling Mice. Anat. Record, 11: 31-40.

LATASTE, F.

1886. Notes Prisés au Jour le Jour sur Differentes Espéces de l'Ordre des Rongeurs

Observées en Captivité. Actes de la Société Linnéenne de Bordeaux, 40 :

LOWENHARdT, P.

4 , series, tome X, p. 295-466, 3 pls.

1872. Die Berechnung und die Dauer der Schwangerschaft. Archiv. für Gynökologie, 3 : 457-491.

NAKamura, Hirosi

1926. Etudes Experimentales sur la Durée de la Gestation de la Souris. Ann. l'Inst. Pasteur, 40: 303-308.

\section{Nelson, E. W.}

1918. Smaller Mammals of North America. Nat. Geogr. Mag., May: 524.

NeLson, W. O.

1929. Oestrous during Pregnancy. Science, 70: 453.

OSGOOD, W. H.

1909. Revision of the Mice of the American Genus Peromyscus. N. A. Fauna, 28 : $1-285$.

PATCH, E. M.

1917. The Aphid of Choke Cherry and Grain. Maine Agr. Exp. Sta. Bull., 267 : 293-297. 


\section{PINARd}

1905. Article "Gestation." Richet's Dictionaire de Physiologie, Paris, 7.

Robson, G. C.

1928. The Species Problem. Biological Monographs and Manuals. Oliver and Boyd, London.

SCHEFFER; T. H.

1924. Notes on the Breeding of Peromyscus. Jour. Mamm., 5: 258.

SELLE, R. M.

1928. Microtus californicus in Captivity. Jour. Mamm., $9: 96$.

SETON, E. T.

1920. Breeding Habits of Captive Deermice. Jour. Mamm., 1: 135.

SHAW, W. T.

1925. Breeding and Development of the Columbian Ground Squirrel. Jour. Mamm., $6: 108$.

Sовотта, J.

1895. Die Befruchtung und Furching des Eies der Maus. Archiv für Mikroskopische Anatomie, 45: 15-93.

Sobotta, J., and Burckhard, G.

1911. Reifung und Befruchtung des Eies der Weissen Ratte. Anatomische Hefte, 42: 435-497.

SUMNeR, F. B.

1916. Superfetation and Deferred Fertilization among Mice. Biol. Bull., 30: 271.

1924. The Stability of Superspecific Characters under Changed Conditions of Environment. Amer. Nat., 58: 481-505.

SvIHLA, ARThur

1929. Breeding Habits and Young of the Red-backed Mouse, Evotomys. Mich. Acad. Sci. Arts and Letters, 11: 486.

1931. Life History of the Texas Rice Rat (Oryzomys palustris texensis). Jour. Mamm., 12: 238-242.

SviHla, Ruth Dowell

1930. Development of Young Red Squirrels. Jour. Mamm., 11: 79-80.

WADE, OTIS

1927. Breeding Habits and Early Life of the Thirteen-striped Ground Squirrel, Citellus tridecemlineatus (Mitchell). Jour. Mamm., 8: 272.

Walton, M. A.

1905. A Hermit's Wild Friends. Estes, Boston: 122. 


